\title{
Self-Concept Transformation on Senior Secondary School Students' Academic Achievement in Central Zone, Plateau State, Nigeria
}

Gwaison Panan Danladi1* ' $h$ htps://orcid.org/0000-0002-9892-7044, Shuaibu Saidu², Jacob, I. Otaha ${ }^{3}$ ${ }^{1}$ Economics and Management Science Department, Nigeria Police Academy, Wudil-Kano, Nigeria 2Science and Technology Education Department, University of Jos, Nigeria

${ }^{3}$ Economics Department University of Jos, Nigeria *e-mail: ${ }^{*}$ panan gwaison@yahoo.com

\section{Article Information}

Received: March 20, 2021

Revised: April 06, 2021

Accepted: April 10, 2021

Online: May 16, 2021

\section{Keywords}

self-concept, academic achievement, transformation package, gender. quantitative economics

\section{ABSTRACT}

Economics is one of the popular subjects in the Senior Secondary School (SSS) curriculum, and it covers the fundamental aspects of human lives concerning scarcity of resources. Proper understanding of the basic concept will enable students to realize the benefit of the subject. This study examined the effects of the self-concept transformation package on senior secondary school student's academic achievement in the quantitative aspect of Economics in Central Zone, Plateau State, Nigeria. A quasi-experimental research design, the non-equivalent control-group design, was used for this study. The sample size consisted of 105 economics SS2 students from intact classes of the four sampled schools. There were 50 and 55 students in the experimental and control group, respectively. Multi-Stage Cluster sampling techniques were used for this study. The instruments used for data collection were the Multidimensional Self-Concept Scales (MSS) and Quantitative Economics Achievement Test (QEAT). Research questions were analyzed using descriptive statistics, while the t-test of independent sample and Analysis of Covariance (ANCOVA) was used to test the hypotheses. The statistical package for social sciences (SPSS) version 23 was used for the analysis. The results show that the self-concept transformation package positively and significantly affected students' self-concept and academic achievement in quantitative economics. The study recommended that the use of abusive words on students by Parents and guardians should be discouraged to strengthening their student's self-concept.

\section{INTRODUCTION}

Education is so powerful that it can heal, build up, and lift a nation. Several government and regimes previously in Nigeria has made Education their priority; however, the Nigerian Educational system is still not ripe to address the challenges of modern times. In Nigeria, despite the several reforms and policy modifications in the educational system such as the 8-6-2-3 system; the 6-5-2-3 system (1954); the 6-3-3-4 systems(1983); and currently the 9-3-4 system (Zalmon, 2017), poor students' performance remains a problematic issue and a thing of concern to stakeholders. As a result, the 
National Policy on Education (NPE) has been revised to ensure that it addresses the educational sector's perceived needs to improve students' performance, yet it has not yielded many results (FRN, 2013).

Economics is one of the popular subjects in the Senior Secondary School (SSS) curriculum, and it covers the fundamental aspects of human lives concerning scarcity of resources. Proper understanding of the basic concept will enable students to realize the benefit of the subject. The subject at secondary levels comprises economics theory, Economics statistics, and Economics mathematics; the quantitative aspect of economics covers economics statistics and Economics mathematics. Unfortunately, despite the popularity of Economics, students' performance is still poor in Economics' examinations (Adu, Ojelabi \& Hammed, 2009). The West African Examination Council (WAEC) Chief Examiners' reports (19992016) on senior secondary school students' achievement in economics revealed poor performance from available statistics. For instance, in 2009, 2013, and 2014 about 45.44 percent, 48.2percent, and 49.7 percent of candidates that sat for the Senior Secondary Certificate Examination (SSCE) in Nigeria, respectively obtained credit passes of between A1 - C6 in Economics (Zalmon, 2017). These performances are shallow compared to the globally accepted standard of 70 percent. The Chief Examiners' report (2016) identified the poor understanding of concepts taught, inadequate coverage of the syllabus, inability to draw and label demand curves properly, inaccurate measurement of diagram outlines, and poor manipulations of demand equations as the causes of poor performance in economics in the secondary schools. Similarly, the Chief Examiners' reports in 2010 and 2012 also indicated that quantitative Economics accounted for 70 percent of students' weaknesses. It can be seen as follows:

1. Calculations; Most students cannot calculate the price elasticity of demand and the total cost, average cost, and marginal cost.

2. Poor graph analysis; The students cannot draw a demand curve and understand total and marginal cost diagrams.

Moreover, it is difficult to study all the factors affecting academic achievement. It is because of the multi-dimensional nature of this variable, and it is affected by huge factors such as student intelligence quotient, School environment, teachers' capacity, availability of instructional materials, students' selfconcept, and students' attitude. It has prompted this study that the solution might lie in the students self-concept.

Self-concept simply is viewed as the intellectual and cognitive aspect of self; this enables an individual to have a total understanding of himself or herself. Self-concept refers to self-awareness, assessment, understanding, and insight about oneself (Hormuth, 2010). Everybody has some perception about himself; hence Self-concept does not necessarily reflect reality. An individual becomes more satisfied when the ideal self is incongruent with the actual self. Social and psychological incompatibility can experience by the individual due to failure to achieve the ideal concept. Therefore, self-concept involves the awareness, feelings, and attitudes one has about one's skills, abilities, social acceptance and appearance, and other features; it is formed through the interaction with the environment, primarily through self-assessment.

Furthermore, gender plays a significant role in determining students' self-concept and academic achievement in secondary schools. The results from studies show a mixed result. The studies of Vleioras and Bosma (2005) indicated a positive relationship between the genders with other's personality development. Also, in the work of Maddux and Brewer (2005) shows that self-concept is one of the differences between male and female this lead to different behaviors in people. Kemmelmeier and Oyserman (2001) stated that male and female differences in excitement, motivation, cognition, and social behaviors could be attributed to the difference between male and female self-concepts. They further mentioned that males and females defined themselves in quite different ways. Females define themselves with others in society, but males define themselves with themselves. However, Marčič and Grum (2011) indicated no significant difference between self-esteem and self-concept among males and females. Social skills, responsibility, citizen responsibilities, honesty, and loyalty are positively related to self-concept. The study indicated that women are more satisfied with others than men, and they are more competent to interact with others, and they are more loyal and honest than men. Since all societies help men and women obtain positive self-concepts to attain self-actualization and flourish their potentialities and talents, examining the differences between genders is of great importance. Kalantarkousheh (2012) opined that gender differences need to be considered in examining psychological factors. Thus, this study examines how male and female students differ in their self- 
concept. However, a student who does not have a positive self-concept may find it challenging to do well in the examination, especially where the syllabus is quantitative. There has been a continuous decline in academic standards in general and weak students' performance in quantitative aspects of economics, particularly in senior secondary schools, as highlighted above. It is against this background that the researcher wants to investigate the effects of self-concept transformation package on senior secondary school students' academic achievement in quantitative aspect of economics in Central Zone, Plateau State, Nigeria.

\section{Literature review}

This study shall be anchored on the Social Learning Theory proposed by Albert Bandura in 1977. The theory believes that all types of learning cannot be accountable for direct reinforcement. Instead, he stated that learning could take place through observing the actions of others. The theory added a social element, arguing that people can learn new information and behaviors by watching other people. Known as observational learning that is modeling a wide variety of behaviors can explain this type of learning.

Social cognitive theory is applied throughout this study to examine the development of the participants and the social cognitive components related to the influence of self-concept on attitude and academic achievement. Social cognitive development comprises many aspects of a child's environment, including parental involvement or parent-child interaction, decision-making skills, communications skills, social skills, peer interactions, and other factors included in a child's self-concept developmental process. In addition, changes in the environment may influence the overall stability of the child; thus, fluctuations in life circumstances were examined, specifically the children's self-concept, which is learned and it is also dynamic. Several Scholars have examined self-concept and academic achievement, and their studies were reviewed below:

Adebule (2014) studied students' self-concept and academic performance in Mathematics in Ekiti State, Nigeria, to confirm their relationship. The study used a descriptive correlational survey design. In addition, the influence of school location on students' self-concept was also examined. Four hundred students were drawn as a sample from four Local Government Areas of Ekiti State using the stratified random sampling technique to cater to urban and rural students. A-25 item instrument called Student Self-Concept Inventory (SSCI) was used. The study tested two hypotheses using Pearson Product Moment Correlation and t-test statistics. The results indicated that self-concept did not influence the academic performance of students.

Ayodele (2011) examined the relationship between self-concept and performance in mathematics and gender on self-concept and performance in Mathematics. The study employed a survey design; A sample of 320 SS1 students (male=160, female=160) participated in the study from 16 secondary schools (urban=8, rural=8) in eight local government areas Ekiti State. To select the local government areas, random sampling was employed, while in selecting the schools and the participants, the stratified random sampling technique was employed. A 20-item self-concept questionnaire and a 30-item multiple-choice Mathematics Achievement Test with reliability coefficients of 0.74 and 0.83 were used for data collection. In addition, Pearson product-moment correlation and t-test statistics, tested at 0.05 level of significance, were used for data analysis. The results indicated that self-concept moderately correlated with performance in Mathematics, while gender had no significant influence on self-concept and performance in Mathematics. However, the mean scores of male and female students in Mathematics were below average. Therefore, it was suggested that teachers help their students develop a positive self-concept towards Mathematics and pleasant teaching experiences to enhance higher selfconcept and better performance in mathematics.

Igbo, Onu, and Obiyo (2015) investigated the influence of gender stereotypes as a predictor of secondary school students' self-concept and academic achievement in Enugu State, Nigeria. There are four objectives, four research questions and, four hypotheses in the study. An ex post facto design was adopted for the study. From 227 schools in the Udi education zone, a sample of 8 public and nine private schools was randomly selected; 342 SSII students randomly selected from the selected schools participated in the study. A 20-item students' stereotype self-concept questionnaire (SSSCQ) was adapted from Marsh's Self Descriptive Questionnaire II (SDQII), and the researchers developed a 10- 
item students' mathematics achievement test (SMAT) from previous literature. Experts were consulted for face and content validation in the instrument development process. The study used In mean and standard deviation to answer the research questions, t-test was used to test hypotheses. The results showed that gender stereotype has a significant influence on students' self-concept and academic achievement in favor of the male students. However, school location has a significant influence on student's academic achievement but has no significant influence on students' self-concept. However, no research addressed the current issues. Most of the researches were carried out in mathematics, English, Social studies, and sciences, but none in Economics or Quantitative Economics. The inclusive results in the previous research and dearth of studies in Plateau state, Nigeria, have initiated a further investigation of the effects of self-concept on academic achievement of senior secondary school students in quantitative Economics. The research design used, the instruments for data collection used, and the data analysis methods employed in the studies reviewed above are gaps that this study will fill. It is because this study will use a quasi-experimental research design, three instruments for data collection, and will employ mean, standard deviation, $t$-test of independents samples, t-test of correlated samples, and analysis of covariance (ANCOVA) for data analysis, which will differ with the one used in the reviewed studies above.

\section{METHODS}

\section{Research Design}

This study used quasi-experimental research design the non-equivalent control- group design. The choice of quasi-experimental research design, the non-equivalent control- group design, is appropriate for this study because of the difficulty in applying accurate experimental methods to social science and education research. Secondly is the high cost of accurate experimental methods. Lastly is the development of statistical tools that enable statistical control in quasi-experimental research design

\section{Populations and sampling techniques}

The study population will consist of all the 9,597 senior secondary two students (SSSII) in the 210 secondary schools in the study area. Thus, the population will cover both private and public secondary schools in the study area. The Central Senatorial Zone of Plateau State comprises Pankshin, Kanke, Kanam, Mangu, and Bokkos Local Government Areas. There are 210 secondary schools in the study areas, made up of 105 public secondary schools and 105 private secondary schools, and there are 5,265 male students and 4,332 female students that offer Economics in the study area. In addition, 5427 SSII students offer Economics in private schools, and 4170 SSII students offer Economics in Public schools. The sample size consisted of 105 economics SS2 students from intact classes of the four sampled schools. The experimental group was made up of 30 males and 20 females, while the control group was 29 males and 26 females. Therefore there are 50, and 55 students in the experimental and control group were selected using multi-Stage Cluster sampling techniques.

\section{Instruments}

The instrument used for data collection were the Multi-dimensional Self-Concept Scales (MSS) and Quantitative Economics Achievement Test (QEAT). The MSS and QEAT instruments were adapted from the Fleming-Courtney revision of the Janis-Field Scale and passed WAEC questions. The reliability of QEAT was sought using the test re-test method of reliability. The reliability coefficient obtained was 0.987. It indicated that the instrument was reliable. Cronbach Alpha method was used to established reliability for MSS, and the result was 0.940 . It indicated that the instruments were all reliable.

\section{Procedure}

Before the commencement of the experiment, MSS and QEAT were administered to experimental and control groups as a pre-test. Students' responses in the two groups were scored and recorded before the treatment was introduced to the experimental group. Two days after the pre-test, the experimental group was taught quantitative aspects of economics using the same conventional method but were exposed to the self-concept transformation package (SCTP) and the control group using the same conventional lesson but were not exposed to the self-concept transformation package(SCTP). At the end of the six weeks of teaching, MSS and QEAT were administered immediately to control and experimental 
groups. The response of students was collected back on the spot and scored by the researcher and research assistants.

\section{Method of Data Analysis}

The method of data analysis was based on the research questions and hypothesis stated. First, research questions 1,2and three were answered using descriptive statistics, like mean and standard deviation. Then, inferential statistics were used to test the hypothesis at a 0.05 level of significance; the t-test of the independent sample was used to test hypotheses1and 2, while Analysis of Covariance (ANCOVA) was used to test hypothesis 3 respectively with the aid of statistical package for social sciences (SPSS) version 23.

\section{RESULTS}

\section{Research Questions}

Descriptive statistics mean and the standard deviation was used to answer the research question below.

\section{Research question one}

What is the difference in the academic achievement of secondary school students in the quantitative aspect of Economics in the experimental and control group before treatment in the Central Senatorial Zone, Plateau State, Nigeria?

\section{Table 1. Pre-Test Academic Achievement of Senior Secondary School Students in Quantitative aspect of Economics}

\begin{tabular}{lllll}
\hline Group & N & $\bar{X}$ & SD & Mean Difference \\
\hline Experimental & 50 & 40.50 & 9.31 & \\
Control & 55 & 40.02 & 9.08 & 0.48 \\
\hline
\end{tabular}

Source: Authors computation 2020

Table 1 reveals the pre-test student quantitative economics mean scores of experimental and control groups. The result for the experimental group has the mean score and standard deviation of $(=40.50, \mathrm{SD}=9.30)$, and that of the control group has the mean score and standard deviation of $(=40.02$, $\mathrm{SD}=9.08)$. Thus, the pre-test student quantitative economics mean scores in both control and experimental groups generally indicated low with a low mean difference(0.48). It could be because both groups were not exposed to treatment.

\section{Research question two}

What is the difference in the academic achievement of secondary school students in the quantitative aspect of Economics in the experimental and control group after treatment in the Central Zone, Plateau State, Nigeria?

Table 2. Post-Test Academic Achievement of Senior Secondary School Students in Quantitative aspect of Economics

\begin{tabular}{lllll}
\hline Group & $\mathbf{N}$ & $\bar{X}$ & SD & Mean Difference \\
\hline Experimental & 50 & 57.40 & 9.24 & 14.36 \\
Control & 55 & 43.04 & 9.08 & \\
\hline
\end{tabular}

Source: Authors computation 2020 
Table 2 reveals the post-test student quantitative economics mean scores of experimental and control groups. The result for the experimental group has the mean score and standard deviation of $(=57.40, S D=9.24)$, and that of the control group has the mean score and standard deviation of $(=43.04$, $\mathrm{SD}=9.08)$. The post-test students' quantitative economics mean scores in experimental and control groups generally improve with a mean difference (14.36). It could be because the experimental groups were exposed to treatment.

\section{Research question three}

What is the difference in students' self-concept after the treatment package in Central Zone, Plateau State, Nigeria?

\section{Table 3. Post-Test Mean Scores of Students self-concept in the experimental and control group}

\begin{tabular}{lllll}
\hline Group & $\mathbf{N}$ & $\bar{X}$ & SD & Mean Difference \\
\hline Experimental & 50 & 74.10 & 8.13 & \\
& & & & 7.35 \\
Control & 55 & 66.75 & 8.81 & \\
\hline
\end{tabular}

Source: Authors computation 2020

Table 3 reveals the post-test student self-concept mean scores of experimental and control groups. The result for the experimental group has the mean score and standard deviation of $(=74.10$, $\mathrm{SD}=8.13)$, and that of the control group has the mean score and standard deviation of $(=66.75, \mathrm{SD}=8.81)$.

The pre-test student quantitative economics attitude mean scores in both experimental and control groups generally indicated high self-concept with a high mean difference (7.35). It could be because experimental groups were exposed to treatment.

\section{Research question four}

What is the difference in males and females students' academic achievement in quantitative economics after the treatment package in Central Zone, Plateau State, Nigeria?

Table 4 The difference in males and females students' academic achievement in quantitative economics after the treatment package

\begin{tabular}{llllll}
\hline Group & Gender & N & $\bar{X}$ & SD & Mean Difference \\
\hline Experimental & Male & 30 & 57.90 & 1.61 & \\
& & & & & 0.83 \\
\multirow{2}{*}{ Control } & Female & 20 & 57.07 & 2.24 & \\
& Male & 29 & 43.07 & 9.22 & \multirow{2}{*}{0.07} \\
& Female & 26 & 43.00 & 9.10 & \\
\hline
\end{tabular}

Source: Authors computation 2020

Table 4 indicated that the academic achievement mean scores after treatment of male students in the experimental group are 57.90 and female students 57.07 with the SD 1.61and 2.24, respectively. However, male students' mean scores in the control group are 43.07 and female students 43.00 with the SD of 9.22 and 9.10, respectively. These results show that male students had better academic achievement in quantitative economics than female students in the control and experimental groups. The means scores of the experimental group were higher than the control groups. It could be because the experimental groups were exposed to treatment. 


\section{Hypotheses}

The first two hypotheses set for this study were tested using a t-test of independent samples, and the other one was tested using ANCOVA with the aids of SPSS version 23 below. The summary of the results was presented below, respectively

\section{Hypothesis One}

There is no significant difference between the pre-test academic achievement mean scores of secondary school students in quantitative Economics in experimental and control groups.

Table 5. Results of t-test analysis for the difference between pre-test academic achievement mean scores of Experimental and Control Groups

\begin{tabular}{lllllll}
\hline Group & $\mathrm{N}$ & $\bar{X}$ & $\mathrm{SD}$ & $\mathrm{Df}$ & $\mathrm{T}$ & $\mathrm{p}$-value \\
\hline Experimental & 50 & 40.50 & 9.30 & & & \\
& & & & 103 & 1.15 & 0.18 \\
Control & 55 & 40.02 & 9.08 & & & \\
\hline
\end{tabular}

Source: Authors computation 2020

Table 5 reveals the t-test for independent sample on pre-test academic achievement mean scores of Experimental and Control Groups. The table shows that the mean value for the experimental and control groups was $(=40.50, \mathrm{SD}=9.30)$ and $(=40.02, \mathrm{SD}=9.08)$. Thus, the t statistics was 1.15 ; since the p-value (0.18) is greater than the 0.05 level of significance, the null hypothesis was retained. Furthermore, it indicated that the pre-test mean scores of the experimental group were not statistically significantly different from the pre-test academic achievement mean scores of secondary school students in the quantitative Economics of the control group. The two groups were thus considered to be equivalent before the commencement of treatment.

\section{Hypothesis two}

There is no significant difference between the post-test academic achievement mean scores of secondary school students in quantitative Economics in the experimental and control group.

Table 6. Results of t-test analysis for the difference between post-test academic achievement mean scores of Experimental and Control Groups

\begin{tabular}{|c|c|c|c|c|c|c|}
\hline Group & $\mathbf{N}$ & $\bar{X}$ & SD & Df & $\mathbf{T}$ & p-value \\
\hline \multirow{2}{*}{ Experimental } & 50 & 57.40 & 9.24 & & & \\
\hline & & & & 103 & 3.10 & 0.002 \\
\hline Control & 55 & 43.05 & 9.08 & & & \\
\hline
\end{tabular}

Source: Authors computation 2020

From table 6, the results show that the post-test mean value for the experimental group and control group were $(=57.40, \mathrm{SD}=9.24)$ and $(=43.05, \mathrm{SD}=9.08)$ respectively. The t statistics was 3.10 ; since the p-value (0.002) is less than the 0.05 level of significance, the null hypothesis was rejected. It indicated that the post-test mean scores of the experimental group were statistically significantly different from the pre-test academic achievement mean scores of secondary school students in the quantitative Economics of a control group. This difference was because of the treatment package used.

\section{Hypothesis three}

There is no significant difference between the mean score of students' self-concept in the posttest of the experimental and control groups. 
Table 7. Results of t-test analysis for the difference between post-test students' self- concept mean scores of Experimental and Control Groups

\begin{tabular}{lllllll}
\hline Group & $\mathbf{N}$ & $\bar{X}$ & SD & Df & T & p-value \\
\hline Experimental & 50 & 74.10 & 8.14 & & & \\
Control & 55 & 66.75 & 8.81 & & & 0.034 \\
\hline
\end{tabular}

Source: Authors computation 2020

Table 7 shows that the post-test means values for the experimental and control groups were $(=74.10, \mathrm{SD}=8.14)$ and $(=66.75, \mathrm{SD}=8.81)$. The $t$ statistics was 2.14 ; since the $\mathrm{p}$-value $(0.034)$ is less than the 0.05 level of significance, the null hypothesis was rejected. It indicated that the post-test mean scores of the experimental group were statistically significantly different from the pre-test students' selfconcept mean scores of the control group. This difference was because of the treatment package used.

\section{Hypothesis four}

There is no significant main effect of gender on students' academic achievement of secondary school students in quantitative Economics before and after the treatment package in experimental and control groups.

Table 8. ANCOVA Summary Results of the main effect of gender on students' academic achievement in quantitative aspect of Economics

\begin{tabular}{llllll}
\hline \multicolumn{1}{c}{ Source } & \multicolumn{1}{c}{$\begin{array}{c}\text { Type III Sum of } \\
\text { Squares }\end{array}$} & Df & Mean Square & \multicolumn{1}{c}{ F } & Sig. \\
\hline Corrected Model & $8474.189 a$ & 2 & 4237.094 & 1952.286 & .000 \\
Intercept & 65.453 & 1 & 65.453 & 30.158 & .000 \\
postQEATALL & 8462.488 & 1 & 8462.488 & 3899.181 & .000 \\
Gender & 256.418 & 1 & 256.418 & 118.147 & .000 \\
Error & 221.373 & 102 & 2.170 & & \\
Total & 178782.000 & 105 & & & \\
Corrected Total & 8695.562 & 104 & & & \\
\hline
\end{tabular}

a. R Squared $=.977$ (Adjusted R Squared $=.976$ )

Source: Authors computation 2020

The ANCOVA was conducted in table 8 to determine the main effect of gender on students' academic achievement of secondary school students in quantitative Economics. The effect of gender ( male and female $)$ yielded a mean of $(=42.58, S D=11.824)$, and $(=35.25, S D=11.833)$, respectively. The result in table 15 further shows that $F(1,40)=118.147$. $P=0.000$. Since the $p$-value of 0.0000 is less than the 0.05 level of significance, the null hypothesis is rejected, indicating a significant effect of gender on students' academic achievement in the quantitative aspect of Economics.

\section{DISCUSSION}

The first findings show no significant difference between the pre-test academic achievement mean scores of secondary school students in quantitative Economics in experimental and control groups. It is because the is no significant difference in the mean of the two groups before treatment. It implies that the two groups were randomly assigned, and both groups were not exposed to treatment. The second findings show a significant difference between the post-test academic achievement mean scores of secondary school students in quantitative Economics in experimental and control groups. The mean scores of the experimental group are higher than the control group. This difference was because of the treatment package used on the experimental group. The third findings show a significant difference between the mean score of students' self-concept in the post-test of experimental and control groups. This difference was also because of the treatment package used on the experimental group. 
Furthermore, Lastly, the study further revealed a significant effect of gender on students' academic achievement in quantitative Economics.

\section{CONCLUSION}

The present study concludes that the self-concept transformation package had positive and significant effects on students' self-concept and academic achievement in quantitative economics. Further, this study also concluded that there is a significant effect of gender on students' academic achievement in quantitative Economics. There was a difference between male and female students' academic achievement and self-concept at the secondary school level.

\section{Recommendation}

Based on the findings, the following recommendations were made;

1. The use of abusive words on students by parents and guardians should be discouraged to strengthening their students' self-concept.

2. Students need to be courageous, independent, creative, confident in judgment, psychologically stable, and less anxious, as this would help them mobilize their efforts to meet the academic challenges and expectations.

3. The Ministry of Education should organize training for teachers, school counselors and, School psychologists on the self-concept transformation package that would help students with low selfconcept to improve

4. The school authorities should design an orientation exercise for new students using a self-concept transformation package to sensitize and enlighten the fresh students. It will undoubtedly remove low self-concept, which is synonymous with low academic performance in the students.

5. There is a need teacher should be committed and objective to help female students to overcome the problems associated with low self-concept, and quantitative economics phobia

6. The government and non-governmental agencies should help in the provision of instructional materials, resources for educational visits as well as employ more qualified teachers with professional training and expertise to teach the students economics

\section{Limitation of these studies}

This study faces some limitations, such as inadequate resources to cover many schools in the zone. In addition, the study was limited to secondary school students; the colleges of education and university students were not captured. Primary data were used for this study. The data collected from the questionnaire administered to the students was another limitation of this study. Time to train assistant researchers and conduct the studies was limited due to the COVID-19 pandemic, which resulted in the closure of schools in Nigeria. The experimental design used instead of other research design which might be used and the method of data analysis used were the limitations of this studies.

\section{Suggestion for Further Studies}

With the limitation above, I will suggest a need to use survey design or longitudinal studies design to examine the following in secondary schools, colleges of education, and universities.

1. The relationship between self-concept and academic performance of students in quantitative aspect of economics in universities

2. The relationship between self-concept and academic performance of students in quantitative aspect of economics in Colleges of education

3. The effects of self-concept transformation package on university students' academic achievement in quantitative aspect of economics in Central Zone, Plateau State, Nigeria.

4. The effects of self-concept transformation package on colleges of education students' academic achievement in quantitative aspect of economics in Central Zone, Plateau State, Nigeria.

\section{Funding and Conflicts of Interest:}

The authors declare that there is no funding and conflicts of interest for this research. 


\section{REFERENCES}

Adebule, S.O. (2014) Self-concept and academic performance in mathematics in secondary school students in Ekiti State, Nigeria. Scholar Journal Of Engineering And Technology, 2(3), 348-351. Available at: https://www.semanticscholar.org/paper/Research-Article-Self-Concept-andAcademic-In-Among-Adebule/fc9db7af43d8a6531360937d13c2dd1a310b4940

Adu, E.O.,Ojelabi, S.A.\& Adeyanju ,H.(2009). Quantitative ability correlates to students' academic achievement in secondary school economics in Oyo State, Nigeria. An International MultiDisciplinary Journal, 3(2),322-333. Available at: https://www.ajol.info/index.php/afrrev/article/view/43633/27155

Ayodele, 0.J.(2011).Self-Concept and performance of secondary school students in mathematics. Journal of Education And Developmental Psychology, 1(1), 176-183. Available at: http://www.ccsenet.org/journal/index.php/jedp/article/view/13911

Bandura, A. (1977). Social Learning Theory. Englewood Cliffs, NJ: Prentice-Hall. Available at: http://www.asecib.ase.ro/mps/Bandura SocialLearningTheory.pdf

Bhat, S.A.(2012). Self-Concept and Academic Achievement of Kashmiri and Pakthooni students. Educational Research And Essay.1(5) 074-078. Available at: https://www.yumpu.com/en/document/view/12199692/self-concept-and-academicachievement-of-kashmiri-and-pakthooni-

Chamundeswari ,S.,Sridevi,V.,\& Kumari, A.(2014). Self-Concept, study habit, and academic achievement of students. International Journal of Humanities Social Science And Education 1(10)47-55. Available at: https://www.arcjournals.org/pdfs/ijhsse/v1-i10/8.pdf

Chief Examiners Report (2016). The West African Examination Council. Lagos: Retrieved From http://www.waecnigeria.org.

Federal Republic of Nigeria(FRN) (2013) National Policy on Education, Lagos, Nigeria. Nigerian Educational Research and Development Council(NERDC) Press. Available at: http://wbgfiles.worldbank.org/documents/hdn/ed/saber/supporting doc/AFR/Nigeria/TC H/National\%20Policy\%20on\%20Education.pdf

Hormuth, S.E 2010. The Ecology of the Self: Relocation and Self-Concept Change, Cambridge University Press. Available at:

http://services.cambridge.org/us/academic/subjects/psychology/personality-psychologyand-individual-differences/ecology-self-relocation-and-self-conceptchange?format $=$ PB\&isbn $=9780521154963$

Igbo, J. N., Onu, V. C., \& Obiyo, N. O. (2015). Impact of Gender Stereotype on Secondary School Students' Self-Concept and Academic Achievement. SAGE Open.

https://doi.org/10.1177/2158244015573934

Kalantarkousheh, S.M. (2012), gender as a moderator in the association of self-acceptance and autonomy of Iranian university students, Journal of Teaching and Education, 1(6) 39-46. Available at: http://drkalantar.com/Farsi/wp-content/uploads/2015/09/GenderModerator.pdf

Kemmelmeier,M. and Oyserman, D. (2001).Gendered influence of downward social comparisons on current and possible selves, Journal of Social Issues, 57(1) 129-148. Available at: https://psycnet.apa.org/record/2001-06338-007

Maddux, W.W. and Brewer, M.B. (2005), Gender differences in the relational and collective bases for trust, Group Processes \& Intergroup Relations, 8(2) 159-171. Available at: https://psycnet.apa.org/record/2005-03939-005 
Marčič, R. and. Grum, D.K. (2011), Gender differences in self-concept and self-esteem components, Studia Psychologica, 53(4) 373-384. Available at: https://psycnet.apa.org/record/2012$\underline{01875-006}$

Vleioras, G.and. Bosma, H.A., (2005) Are identity styles important for psychological wellbeing? Journal of Adolescence, 28(3), 397-409. Available at: https://pubmed.ncbi.nlm.nih.gov/15925690/

Zalmon, I. G., \& Wonu, N. (2017). Comparative analysis of student mathematics achievement in West African senior secondary certificate examination in Nigeria. European journal of research and reflection in educational sciences, 5(1). http://www.idpublications.org/wpcontent/uploads/2016/12/fULL-pAPER-COMPARATIVE-ANALYSIS-OF-STUDENTMATHEMATICS-ACHIEVEMENT-IN-WEST-AFRICAN-SENIOR-SECONDARY-CERTIFICATE.pdf 